\title{
ARBITRASE SEBAGAI ALTERNATIF PENYELESAIAN SENGKETA
}

\author{
Muskibah \\ Dosen Fakultas Hukum Universitas Jambi \\ Email : muskibah@yahoo.co.id
}

\begin{abstract}
ABSTRAK
Penyelesaian sengketa melalui arbitrase dapat dilakukan dengan klausula arbitrase yang berbentuk pactum de compromittendo dan klausula arbitrase yang berbentuk acta compromise. Lembaga arbitrase yang dapat dipilih oleh para pihak untuk menyelesaikan sengketa, terdiri atas Arbitrase ad hoc dan Arbitrase institusional. Mekanisme penyelesaian sengketa dimulai dari tahap pemberitahuan dan jawaban kepada para pihak, kemudian diikuti dengan pemilihan dan pengangkatan arbiter, dan diakhiri dengan pemeriksaan dan putusan. Kekuatan hukum dari putusan arbitrase adalah bersifat final dan mengikat, tetapi pengakuan dan pelaksanaan putusannya tetap harus didaftarkan ke Pengadilan Negeri.
\end{abstract}

Kata Kunci : Penyelesaian Sengketa, Arbitrase.

\section{ABSTRACT}

Dispute settlement by means of arbitration can be conducted by using the arbitration clause of pactum de compromittendo and acta compromise. The choice of the arbitration institution chosen by the disputing parties consists of ad hoc arbitration and institutionalized arbitration. Dispute settlement mechanism commences from the notification stage and responses to the parties, followed by the choice and appointment of the arbitrators, and ended by hearing session and award rendered by the arbitrators. Arbitral award given by arbitrators has a legal and binding force, but the recognition and the implementation of the said award requires submission of registration for arbitral award through District Court.

Keywords: Dispute Settlement, Arbitration

\section{Pendahuluan}

Secara konvensional, penyelesaian sengketa dilakukan melalui proses litigasi (pengadilan). Akan tetapi penyelesaian sengketa melalui proses litigasi cenderung menghasilkan masalah baru karena sifatnya yang winlose, tidak responsif, time consuming proses berperkaranya, dan terbuka untuk umum (Frans Hendra, 2011:9). Kemudian dalam proses litigasi ini, dapat diajukan upaya hukum atas putusan yang dijatuhkan hakim kepada pengadilan yang lebih tinggi
(Retnowulan Sutantio dan Iskandar Oeripkartawinata, 1998:68).

Sehubungan dengan hal di atas, penyelesaian sengketa di luar pengadilan menjadi pilihan alternatif para pihak yang bersengketa. Salah satu penyelesaian sengketa di luar pengadilan tersebut adalah melalui forum arbitrase. Pasal 60 UndangUndang Nomor 30 Tahun 1999 tentang Arbitrase dan Alternatif Penyelesaian Sengketa (selanjutnya disingkat UU AAPS) menyebutkan putusan arbitrase bersifat final dan mempunyai kekuatan 
hukum tetap dan mengikat para pihak. Artinya putusan arbitrase tersebut tidak dapat diajukan upaya hukum banding, kasasi, atau peninjauan kembali. Berdasarkan ketentuan Pasal 59 angka (1) dan (4) UU AAPS, sifat final dan mengikat putusan arbitrase tersebut digantungkan pada kewajiban untuk mendaftarkan putusan arbitrase ke Pengadilan Negeri sehingga putusan tersebut dapat dilaksanakan. Kemudian berdasarkan ketentuan Pasal 70 UU AAPS, putusan arbitrase yang bersifat final dan mengikat tersebut masih dapat diajukan upaya pembatalan apabila putusan arbitrase mengadung unsur-unsur yang telah diatur, antara lain sebagai berikut:

1. Surat atau dokumen yang diajukan dalam pemeriksaan, setelah putusan dijatuhkan, diakui palsu atau dinyatakan palsu;

2. Setelah putusan diambil ditemukan dokumen yang bersifat menentukan, yang disembunyikan oleh pihak lawan; atau

3. Putusan diambil dari hasil tipu muslihat yang dilakukan oleh salah satu pihak dalam pemeriksaan sengketa.

Ketentuan Pasal 70 UU AAPS tidak sejalan dengan penjelasannya, karena dalam penjelasan Pasal 70 UU AAPS disebutkan bahwa alasan-alasan pembatalan yang ditetapkan dalam Pasal 70 UU AAPS harus dibuktikan dengan putusan pengadilan. Putusan pengadilan tersebut dapat digunakan sebagai dasar pertimbangan hakim untuk mengabulkan atau menolak permohonan pembatalan putusan arbitrase. Penjelasan Pasal 70 UU AAPS ini kemudian dibatalkan berdasarkan
Putusan Mahkamah Konstitusi No. 15/PUU-XII/2014, yang menyatakan bahwa Penjelasan Pasal 70 UU AAPS bertentangan dengan UUD 1945 dan tidak mempunyai kekuatan mengikat. Berdasarkan putusan Mahkamah Konstitusi tersebut, alasan-alasan permohonan pembatalan arbitrase tidak harus dibuktikan di pengadilan.

Putusan arbitrase yang bersifat final dan mengikat tersebut pada kenyataannya belum merupakan putusan yang final dan mengikat, karena putusan arbitrase yang bersifat final dan mengikat tersebut baru dapat dilaksanakan setelah didaftarkan ke pengadilan. Dalam hal para pihak tidak bersedia memenuhi pelaksanaan putusan tersebut secara sukarela, putusan tersebut dapat dilaksanakan berdasarkan perintah Ketua Pengadilan Negeri atas permohonan salah satu pihak yang bersengketa. Di sisi lain putusan arbitrase tersebut juga dapat dimintakan pembatalan ke Pengadilan Negeri (Pasal 60, Pasal 61, dan Pasal 70 UU AAPS.).

Pendaftaran putusan arbitrase ke Pengadilan Negeri untuk memperoleh kekuatan mengikat serta upaya pembatalan putusan arbitrase menunjukan adanya penyimpangan terhadap asas final dan mengikat yang diatur dalam Pasal 60 UU AAPS dan asas kebebasan berkontrak yang terdapat dalam Pasal 1338 KUHPerdata. Para pihak yang telah sepakat mengadakan perjanjian arbitrase dan menyerahkan proses penyelesaian sengketanya melalui arbitrase, terikat untuk mentaati dan melaksanakan putusan arbitrase tersebut tanpa harus menunggu eksekusi dari pengadilan. Adanya 
peluang untuk mengajukan perlawanan melalui upaya pembatalan putusan ke Pengadilan Negeri pada akhirnya menimbulkan ketidakpastian dalam penyelesaian sengketa melalui arbitrase.

Arbitrase adalah cara penyelesaian suatu sengketa perdata di luar pengadilan umum yang didasarkan pada perjanjian arbitrase yang dibuat secara tertulis oleh para pihak yang bersengketa. Kemudian dalam Pasal 1 angka (3) dijelaskan bahwa yang dimaksud dengan perjanjian arbitrase adalah suatu kesepakatan berupa klausul arbitrase yang tercantum dalam suatu perjanjian tertulis yang dibuat para pihak sebelum timbul sengketa, atau suatu perjanjian arbitrase tersendiri yang dibuat para pihak setelah timbul sengketa.

Berdasarkan rumusan tersebut, dapat disimpulkan kalau perjanjian arbitrase timbul karena adanya suatu kesepakatan berupa, klausul arbitrase yang tercantum dalam perjanjian tertulis yang dibuat para pihak sebelum timbul sengketa, dan suatu perjanjian arbitrase tersendiri yang dibuat oleh para pihak setelah timbul sengketa. Dengan kata lain, klausul arbitrase tersebut dapat dibedakan atas 2 (dua) macam, yaitu: "Klausul arbitrase yang berbentuk pactum de compromittendo dan klausul arbitrase yang berbentuk acta compromise" (Rahmadi Usman, Op. Cit:158).

Menurut Susilawetty, perbedaan antara pactum de compromittendo dan akta kompromis adalah sebagai beriktu :

a. Pactum de Compromittend

Pada bentuk pactum de compromittendo, para pihak sudah mencantumkan dalam kontrak yang mereka buat yakni jika terjadi sengketa di antara mereka dikemudian hari maka mereka sudah menentukan lembaga arbitrase yang akan menyelesaikan sengketa tersebut. Hal ini sesuai dengan bunyi Pasal 4 ayat (2) bahwa persetujuan untuk menyelesaikan sengketa melalui arbitrase sebagaimana dimaksud ayat (1) dimuat dalam suatu dokumen yang ditandatangani oleh para pihak.

b. Akta Kompromis

Akta kompromis dibuat setelah timbul perselisihan di antara kedua belah pihak. Jadi di samping para pihak sudah menentukan pada saat kontrak dibuat, berdasarkan Pasal 7 undang-undang ini para pihak dapat menyetujui suatu sengketa yang terjadi atau akan terjadi di antara mereka untuk diselesaikan melalui arbitrase (Susilawetty, 2013:4).

Berkaitan dengan isi dari klausul arbitrase tersebut baik yang dibuat sebelum atau sesudah timbul sengketa, menurut Suyud Margono "harus berisikan hal-hal yang boleh dicantumkan dalam perjanjian arbitrase. Penggunaan istilah klausul arbitrase mengandung konotasi bahwa perjanjian pokok yang bersangkutan diikuti atau dilengkapi dengan persetujuan mengenai pelaksanaan arbitrase" (Suyud Margono, 2004:117). Selanjutnya menurut Gatot Soemartono isi klausul arbitrase seharusnya "menunjuk sebuah badan arbitrase 
tertentu, lokasi arbitrase berlangsung, hukum dan aturan yang akan digunakan, kualifikasi para arbiter, dan bahasa yang akan dipakai dalam proses arbitrase" (Gatot Soemartono, 2006:33).

Kemudian terhadap klausul arbitrase berlaku suatu prinsip yang berlaku umum yakni prinsip separabilitas yaitu, "perjanjian atau klausula arbitrase berdiri sendiri dan terlepas sama sekali dari perjanjian pokoknya. Oleh sebab itu, jika misalnya karena alasan apapun perjanjian pokoknya dianggap cacat hukum atau tidak sah, kontrak atau klusula arbitrase tetap dianggap sah dan mengikat" (Moch. Faisal Salam, 2007:150-151).

Untuk mengantisipasi timbulnya persoalan di kemudian hari yang terkait dengan klausul arbitrase dalam proses persidangan dan pelaksanaan putusan arbitrase, seharusnya klausul arbitrase memuat pernyataan mengenai jenis lembaga arbitrase yang dipilih, bagaimana pelaksanaannya, serta peraturan prosedural apa yang akan diterapkan.

Ada 2 (dua) jenis arbitrase yang dapat dipilih oleh para pihak untuk menyelesaikan sengketanya, yakni Arbitrase ad hoc dan Arbitrase institusional. Arbitrase ad hoc dibentuk dalam hal terdapat kesepakatan para pihak dengan mengajukan permohonan kepada Ketua Pengadilan Negeri, untuk menunjuk seorang arbiter atau lebih dalam rangka penyelesaian sengketa para pihak. Arbitrase ini tidak terkait dengan salah satu badan arbitrase, dengan demikian arbitrase ini tidak memiliki aturan tata cara tersendiri, baik mengenai pengangkatan arbiternya maupun tata cara pemeriksaan sengketa. Dalam hal ini, menurut $M$. Yahya Harahap "abitrase ad hoc tunduk sepenuhnya mengikuti aturan tata cara yang ditentukan dalam perundangundangan" (M. Yahya Harahap, 1991:150).

Berbeda dengan arbitrase ad hoc, arbitrase institusional adalah arbitrase yang melembaga yang didirikan dan melekat pada suatu lembaga tertentu. Sifat arbitrase ini permanen dan sengaja dibentuk guna menyelesaikan sengketa, dan pada umumnya memiliki prosedur dan tata cara pemeriksaan sengketa tersendiri, dan apabila selesai memutus sengketa, arbitrase ini tidak akan berakhir. Ada beberapa lembaga yang menyediakan jasa arbitrase institusional, yakni:

a. Arbitrase institusional yang bersifat nasional, yaitu arbitrase yang ruang lingkup keberadaan dan yurisdiksinya hanya meliputi kawasan Negara yang bersangkutan.

a) Badan Arbitrase Nasional Indonesia (BANI)

b) Nederlands Arbitrage Institut

b. Arbitrase institusional yang bersifat internasional, yaitu arbitrase yang ruang lingkup keberadaan dan yurisdiksinya bersifat internasional, misalnya;

a) Court of Arbitration of the International Chamber of Commerce (ICC)

b) The International Centre for Settlement of Investment Dispute (ICSID)

c. Arbitrase institusional yang bersifat regional, yaitu arbitrase yang ruang lingkup keberadaan dan yurisdiksinya berwawasan 
regional, misal Regional Centre for Arbitration yang didirikan oleh Asia-Africa Legal Consultative Committee (AALC) (Faisal Salam, Op.Cit:154).

Berkaitan dengan penyelesaian sengketa melalui arbitrase, meskipun klausul arbitrase bukan materi pokok dari perjanjian yang menimbulkan sengketa tetapi klausul arbitrase merupakan salah satu bentuk dari perjanjian untuk menyelesaikan sengketa antara para pihak yang terikat dalam kontrak, maka keabsahan klausul arbitrase harus diperhatikan apakah kalusul arbitrase tersebut sudah memenuhi syarat-syarat perjanjian yang termuat dalam Buku III KUHPerdata, sehingga proses penyelesaian sengketa dapat dilakukan.

Selanjutnya apabila para pihak telah memilih salah satu dari jenis arbitrase apakah itu arbitrase ad hoc, atau arbitrase institusional sebagaimana yang telah dikemukakan di atas, maka lembaga arbitrase tersebut akan memeriksa dan memutus sengketa para pihak sesuai dengan kewenangan dan prosedur yang ditetapkan oleh lembaga abitrase yang dipilih. Putusan lembaga arbitrase tersebut bersifat final dan mengikat. Akan tetapi kekuatan hukum putusan arbitrase ini masih digantungkan pada proses eksekusi yang dilakukan oleh Pengadilan Negeri.

Berdasarkan hal-hal yang telah dikemukakan tersebut, tulisan ini akan mengkaji mengenai mekanisme penyelesaian melalui arbitrase serta kekuatan hukum dari putusan arbitrase.

\section{Rumusan Masalah}

Adapun pokok permasalahan yang akan dibahas dalam tulisan ini adalah:

1. Bagaimanakah mekanisme penyelesaian sengketa melalui arbitrase?

2. Bagaimanakah kekuatan hukum putusan arbitrase dalam penyelesaian sengketa?

\section{Pembahasan \\ Mekanisme Penyelesaian Sengketa Melalui Arbitase}

Istilah arbitrase berasal dari bahasa latin yaitu "Arbitrare". Arbitrase juga dikenal dengan sebutan atau istilah lainnya yang memiliki maksud yang sama, misalnya Perwasitan atau Arbitrage (Belanda), Arbitration (Inggris), Arbitrage atau Schiedsprush (Jerman), Arbitrage (Perancis), kesemuanya memiliki arti yang sama yaitu kekuasaan untuk menyelesaikan sesuatu menurut kebijaksanaan (Ibid).

Berikut ini beberapa pengertian arbitrase yang dikemukan oleh para ahli hukum, yakni menurut R. Subekti arbitrase adalah "penyelesaian atau pemutusan sengketa oleh seorang hakim atau para hakim berdasarkan persetujuan bahwa para pihak akan tunduk pada atau manaati keputusan yang diberikan oleh hakim atau para hakim yang mereka pilih atau tunjuk" (R. Subekti, 1992:1). Selanjutnya Priyatna Abdurrasyid memberikan pengertian arbitrase adalah:

Salah satu mekanisme alternative penyelesaian sengketa (APS) yang merupakan bentuk tindakan hukum yang diakui oleh undang-undang dimana salah satu pihak atau lebih menyerahkan sengketanya 
ketidaksepahamannya

ketidaksepakatannya dengan satu pihak lain atau lebih kepada satu orang (arbiter) atau lebih (arbiterarbiter majelis) ahli yang professional, yang akan bertindak sebagai hakim / peradilan swasta yang akan menerapkan tata cara hukum Negara yang berlaku atau menerapkan tata cara hukum perdamaian yang telah disepakati para pihak tersebut terdahulu untuk sampai kepada putusan yang final dan mengikat. Oleh karena itu dikatakan bahwa arbitrase adalah hukum prosedur dan hukum para pihak ("law of procedure" dan "law of the parties". Selain putusan arbiter yang final dan mengikat, dikenal pula pendapat mengikat ("binding opinion"-"binded adves)" (Priyatna Abdurrasyid, Op.Cit:56-57).

Kemudian Abdul Kadir Muhammad memberikan pengertian arbitrase yang lebih terperinci yakni:

Arbitrase adalah badan peradilan swasta di luar lingkungan peradilan umum, yang dikenal khusus dalam dunia perusahaan. Arbitrase adalah peradilan yang dipilih dan ditentukan sendiri secara sukarela oleh pihakpihak pengusaha yang bersengketa. Penyelesaian sengketa di luar pengadilan Negara merupakan kehendak bebas pihak-pihak. Kehendak bebas ini dapat dituangkan dalam perjanjian tertulis yang mereka buat sebelum atau sesudah terjadi sengketa sesuai dengan asas kebebasan berkontrak dalam hukum perdata (Abdul Kadir Muhammad, 1993:276).
Selanjutnya secara yuridis, pengertian arbitrase telah dirumuskan dalam Pasal 1 angka 1 UU Nomor 30 Tahun 1999 sebagaimana telah dikemukakan sebelumnya, yakni "arbitrase adalah cara penyelesaian suatu sengketa perdata di luar peradilan umum yang didasarkan pada perjanjian arbitrase yang dibuat secara tertulis oleh para pihak yang bersengketa".

Dari berbagai pengertian tersebut di atas, dapat disimpulkan bahwa arbitrase merupakan cara penyelesaian sengketa perdata di luar peradilan umum yang didasarkan pada perjanjian tertulis yang telah diadakan oleh para pihak yang bersengketa, baik sebelum maupun sesudah terjadinya sengketa. Pihak yang menyelesaikan sengketa disebut dengan arbiter yang dipilih oleh para pihak yang bersengketa.

Arbitrase di Indonesia pada awalnya diatur dalam Reglement op de Burgelijke Rechtsvordering (RV), yang merupakan produk Pemerintah Belanda. Ketentuan dalam RV tersebut masih berlaku setelah Indonesia merdeka dikarenakan adanya peraturan peralihan dalam Undang-Undang Dasar 1945. Akan tetapi dengan berlakunya Undang-Undang Nomor 30 Tahun 1999 Tentang Arbitrase dan Alternatif Penyelesaian Sengketa, maka ketentuan arbitrase dalam RV dinyatakan tidak berlaku lagi.

Sesuai dengan UU Nomor 30 Tahun 1999, mekanisme penyelesaian sengketa jasa konstruksi melalui arbitrase mengikuti ketentuan yang diatur dalam undang-undang ini. Adapun persyaratan yang harus dipenuhi sebelum proses penyelesaian sengketa jasa konstruksi melalui arbitrase dimulai, pertama keharusan adanya perjanjian arbitrase 
yang sah antara pihak pengguna jasa konstruksi dan pihak penyedia jasa konstruksi. Syarat kedua yakni sengketa yang terjadi antara pengguna jasa konstruksi dengan penyedia jasa konstruksi harus merupakan sengketa yang dapat diselesaikan melalui arbitrase.

Suatu perjanjian arbitrase dikatakan sah apabila memenuhi ketentuan mengenai syarat sahnya perjanjian yang termuat dalam Pasal 1320 KUHPerdata, yakni:

a. kesepakatan para pihak

b. kecakapan untuk membuat perjanjian

c. suatu hal tertentu

d. suatu sebab yang halal

Syarat subyektif perjanjian arbitrase terlihat dari keharusan bahwa perjanjian arbitrase tersebut dibuat oleh mereka yang oleh hukum dianggap cakap dan mempunyai wewenang untuk melakukan perjanjian. Sedangkan syarat obyektif dalam perjanjian arbitrase terlihat dari obyek perjanjian arbitrase adalah hanya untuk sengketa di bidang perdagangan dan mengenai hak yang menurut hukum dan aturan perundangundangan dikuasai sepenuhnya oleh pihak yang bersengketa.

Kemudian perjanjian arbitrase tersebut harus dibuat sebelum atau setelah adanya sengketa dalam bentuk tertulis, bentuk tertulis tersebut termasuk dengan menggunakan teleks, telegram, faksimili, e mail atau sarana telekomunikasi lainnya sebagaimana ditentukan dalam Pasal 4 ayat (3) UU Nomor 30 Tahun 1999. Perjanjian arbitrase ini tunduk pada prinsip otonomi para pihak sebagaimana yang diatur dalam Pasal 1338 ayat (1) KUHPerdata. Dengan kata lain proses arbitrase ditentukan dan disepakati sendiri oleh para pihak.

Hal ini sejalan dengan pendapat yang dikemukakan Priyatna Abdurrasyid yakni, ada tiga keadaan yang menyebabkan perjanjian arbitrase menjadi sah dan dapat dilaksanakan oleh para pihak bilamana memenuhi syarat-syarat sebagai berikut:

a. Perjanjian harus tertulis

b. Para pihak harus secara hukum mampu untuk menutup dan melaksanakan perjanjian yang ditandatanganinya

c. Perjanjian harus dengan secara jelas menjabarkan maksud dan persetujuan dari para pihak dalam perjanjian, masalah apa yang diperjanjikan dan dilarang berisikan ketentuan yang diarahkan untuk menolak kekuasaan hukum arbitrase (Priyatna Abdurrasyid, $O p$. Cit:114).

Selanjutnya syarat kedua yakni sengketa yang dapat diselesaikan melalui arbitrase menurut Pasal 5 ayat (1) UU Nomor 30 Tahun 1999 adalah sengketa di bidang perdagangan dan hak yang menurut hukum dan peraturan perundang-undangan dikuasai sepenuhnya oleh pihak yang bersengketa. Dalam penjelasan Pasal 66 huruf b UU Nomor 30 Tahun 1999 disebutkan bahwa yang termasuk ruang lingkup perdagangan adalah kegiatankegiatan di bidang perniagaan, perbankan, keuangan, penanaman modal, industri, dan hak kekayaan intelektual. Usaha jasa konstruksi termasuk dalam bidang insdustri, oleh karena itu sengketa jasa konstruksi dapat diselesaikan melalui arbitrase. 
Adapun mekanisme penyelesaian sengketa jasa konstruksi melalui arbitrase adalah sebagai berikut:

1. Tahap Pemberitahuan

Tahap pertama untuk memulai arbitrase adalah penyampaian pemberitahuan secara tertulis oleh salah satu pihak dalam kontrak kontruksi (disebut Pemohon) kepada pihak lainnya (disebut Termohon), bahwa syarat-syarat penyelesaian melalui arbitrase telah berlaku, dalam hal ini apabila para pihak menyepakati arbitrase ad hoc. Akan tetapi jika para pihak memilih arbitrase institusionial, maka permohonan arbitrase dikirim kepada lembaga institusional yang dipilih, misalnya melalui BANI, untuk kemudian disampaikan kepada pihak lainnya. Tanggal penerimaan pemberitahuan atau permohonan arbitrase dianggap sebagai saat dimulainya tahap arbitrase. Surat pemberitahuan yang merupakan permohonan untuk mengadakan arbitrase tersebut menurut Pasal 8 ayat 1 dan 2 UU Nomor 30 Tahun 1999, harus memuat dengan jelas:

a. Nama dan alamat para pihak

b. Penunjukan kepada klausula atau perjanjian arbitrase yang berlaku

c. Perjanjian atau masalah yang menjadi sengketa

d. Dasar tuntutan dan jumlah yang dituntut, apabila ada

e. Cara penyelesaian yang dikehendaki

f. Perjanjian yang diadakan oleh para pihak tentang jumlah arbiter atau apabila tidak pernah diadakan perjanjian semacam itu, pemohon dapat mengajukan usul tentang jumlah arbiter yang dikehendaki dalam jumlah ganjil.

Apabila para pihak memilih arbitrase setelah sengketa terjadi, maka persetujuan mengenai hal tersebut harus dibuat dalam suatu perjanjian tertulis yang ditandatangani oleh para pihak atau dalam bentuk akta notaris. Perjanjian tertulis tersebut menurut Pasal 9 ayat (3) UU Nomor 30 Tahun 1999 harus memuat:

a. Masalah yang dipersengketakan

b. Nama lengkap dan tempat tinggal para pihak

c. Nama lengkap dan tempat tinggal arbiter atau majelis arbitrase

d. Tempat arbiter atau majelis arbitrase akan mengambil keputusan

e. Nama lengkap sekretaris

f. Jangka waktu penyelesaian sengketa

g. Pernyataan kesediaan dari arbiter

h. Pernyataan kesediaan dari pihak yang bersengketa untuk menanggung segala biaya yang diperlukan untuk penyelesaian sengketa melalui arbitrase

Perjanjian tertulis yang tidak memenuhi ketentuan Pasal 9 ayat (3) tersebut di atas adalah batal demi hukum. Perjanjian arbitrase yang dibuat secara tertulis tersebut berfungsi sebagai pembuktian akan adanya kesepakatan para pihak untuk menyelesaikan sengketa melalui arbitrase, sekaligus mengesampingkan kewenangan pengadilan untuk mengadili sengketa yang bersangkutan. 
Hal ini sejalan dengan ketentuan Pasal 3 dan Pasal 11 ayat (1) UU Nomor 30 Tahun 1999, yang menyebutkan bahwa pengadilan negeri tidak berwenang untuk mengadili para pihak yang terikat dalam perjanjian arbitrase.

Terhadap pemberitahuan atau permohonan arbitrase tersebut pihak termohon dapat mengajukan jawaban dan atau tuntutan balik kepada pemohon. Jawaban atau tuntutan balik tersebut menurut UU Nomor 30 Tahun 1999 dapat diajukan 14 hari sejak salinan permohonan arbitrase diterima termohon. Mengenai isi jawaban dan atau tuntutan balik dari termohon, dalam UU Nomor 30 Tahun 1999 tidak ada pengaturannya, karena itu isi jawaban dan atau tuntutan mengikuti bentuk dan isi dari pemberitahuan atau permohonan arbitrase yang disampaikan oleh pemohon.

2. Tahap Pemilihan dan Pengangkatan Arbiter

Arbiter adalah hakim yang dipilih oleh para pihak yang bersengketa. Berdasarkan Pasal 12 ayat (1) UU Nomor 30 Tahun 1999, yang dapat ditunjuk atau diangkat menjadi arbiter harus memenuhi syarat-syarat sebagai berikut:

a. Cakap melakukan tindakan hukum

b. Berumur paling rendah 35 tahun

c. Tidak mempunyai hubungan keluarga sedarah atau semenda sampai dengan derajat kedua dengan salah satu pihak bersengketa

d. Tidak mempunyai kepentingan finasial atau kepentingan lain atas putusan arbitrase

\section{e. Memiliki pengalaman serta menguasai secara aktif di bidangnya paling sedikit 15 tahun.}

Kemudian dalam ayat (2) disebutkan bahwa "Hakim, jaksa, panitera dan pejabat peradilan lainnya tidak dapat ditunjuk atau diangkat sebagai arbiter". Ketentuan pasal ini dimaksudkan agar terjamin objektivitas dalam pemeriksaan serta pemberian putusan oleh arbiter.

Mengenai ketentuan jumlah arbiter, dapat dilihat dalam rumusan Pasal 1 angka (7) UU Nomor 30 Tahun 1999, yakni: "Arbiter adalah seorang atau lebih yang dipilih oleh para pihak yang bersengketa atau yang ditunjuk oleh pengadilan negeri atau oleh lembaga arbitrase, untuk memberikan putusan mengenai sengketa tertentu yang diserahkan penyelesaiannya melalui arbitrase". Dengan demikian jumlah arbiter, bisa seorang saja yang merupakan arbiter tunggal, atau beberapa orang yang merupakan majelis arbitrase, yang bertugas menyelesaikan sengketa melalui arbitrase.

Pengangkatan arbiter dilakukan berdasarkan penunjukan para pihak, baik melalui pactum de compromittendo maupun akta compromise. Apabila para pihak belum menentukan cara penunjukan arbiter, baik sebelum maupun sesudah sengketa terjadi, para pihak masih diberikan kesempatan untuk memilih arbiter secara langsung.

Dalam hal para pihak tidak sepakat mengenai pemilihan arbiter atau tidak ada ketentuan yang dibuat mengenai pengangkatan arbiter, Ketua Pengadilan Negeri dapat menunjuk arbiter atau majelis arbiter. Begitu juga dalam suatu 
arbitrase ad hoc bagi setiap ketidaksepakatan dalam penunjukan arbiter, para pihak dapat meminta kepada Ketua Pengadilan Negeri untuk menunjuk seorang arbiter atau lebih. Sedangkan dalam arbitrase institusional, pemohon dapat menunjuk sendiri arbiter atau menyerahkan penunjukannya kepada lembaga arbitrase yang bersangkutan.

Dalam Peraturan Prosedur Arbitrase BANI (BANI Rules and Prosedures), ditentukan syarat umum untuk menjadi arbiter, yakni harus terdaftar sebagai arbiter BANI atau memiliki sertifikat ADR/Arbitrase yang diakui BANI. Arbiter yang disediakan BANI terdiri dari berbagai profesi baik pakar hukum maupun pakar non hukum seperti ahli teknik, arsitek, dan orang-orang lainnya yang memenuhi syarat.

Kemudian secara tegas dalam Peraturan Prosedur BANI juga disebutkan bahwa apabila perjanjian arbitrase atau klausul arbitrase menunjuk BANI sebagai badan arbitrase yang akan memutus sengketa, atau apabila dengan tegas disebutkan bahwa pemutusan sengketa akan dilakukan oleh sesuatu badan arbitrase "berdasarkan Peraturan Prosedur BANI", maka BANI berkompetensi untuk menangani sengketa dan sengketa tersebut akan diperiksa dan diputus menurut ketentuan-ketentuan BANI (Gatot Soemartono, Op.Cit:34).

Untuk menjaga kemandirian dan ketidakberpihakan arbiter baik dalam proses pengangkatannya maupun selama arbitrase berlangsung, maka para pihak yang bersengketa dapat mengajukan perlawanan atau tuntutan ingkar. Pasal 22 UU ayat (1) UU Nomor
30 Tahun 1999 menyebutkan: "Terhadap arbiter dapat diajukan tuntutan ingkar apabila terdapat cukup alasan dan cukup bukti otentik yang menimbulkan keraguan bahwa arbiter akan melakukan tugasnya tidak secara bebas dan akan berpihak dalam mengambil keputusan". Kemudian ayat (2) menyebutkan: "Tuntutan ingkar terhadap seorang arbiter dapat pula dilaksanakan apabila terbukti adanya hubungan kekeluargaan, keuangan, atau pekerjaan dengan salah satu pihak atau kuasanya".

Tuntutan ingkar terhadap arbiter tersebut berdasarkan Pasal 23 UU Nomor 30 Tahun 1999, ditujukan kepada:

a. Ketua Pengadilan Negeri, dalam hal arbiter diangkat oleh Ketua Pengadilan Negeri

b. Arbiter yang bersangkutan, dalam hal sengketa diselesaikan oleh arbiter tunggal

c. Majelis arbiter, dalam hal sengketa diselesaikan oleh mejelis arbiter.

Tuntutan ingkar harus diajukan secara tertulis dengan menyebutkan alasannya, baik kepada pihak lainnya maupun kepada arbiter yang bersangkutan. Apabila tuntutan ingkar disetujui, arbiter yang bersangkutan mengundurkan diri. Akan tetapi jika tidak disetujui pihak lainnya dan arbiter tidak mengundurkan diri, pihak yang berkepentingan dapat mengajukan tuntutan ke Pengadilan Negeri.

3. Tahap Pemeriksaan Sengketa dan Putusan

Dalam pemeriksaan sengketa, apabila para pihak tidak menentukan atau tidak memilih aturan procedural arbitrase institusional tertentu, maka 
pemeriksaan sengketa baik oleh arbiter atau majelis arbitrase dilakukan menurut ketentuan dalam UU Nomor 30 Tahun 1999. Dalam hal para pihak menentukan sendiri lembaga arbitrase institusionalnya, apakah akan menggunakan lembaga arbitrase nasional atau internasional maka penyelesaian sengketa didasarkan pada aturan prosedural dari lembaga arbitrase institusional tersebut baik yang nasional maupun internasional seperti dari BANI, ICC, AAA, LCIA, dan UNCITRAL.

Pemeriksaan sengketa dalam arbitrase dilakukan secara tertulis, pemeriksaan lisan dapat dilakukan jika disetujui para pihak atau dianggap perlu oleh arbiter atau majelis arbitrase. Kemudian mengenai tempat arbitrase ditentukan oleh arbiter atau majelis arbitrase, kecuali ditentukan sendiri oleh para pihak. Ketentuan mengenai tempat arbitrase ini diatur dalam Pasal 37 ayat (1) UU Nomor 30 Tahun 1999.

Ketentuan mengenai tempat arbitrase ini penting terutama apabila terdapat unsur hukum asing dan sengketa menjadi suatu sengketa hukum perdata internasional. Apabila para pihak tidak menentukan sendiri tempat arbitrase, maka arbiter dapat menentukan tempat arbitrase.Tempat arbitrase tersebut dilakukan dapat menentukan hukum yang harus dipergunakan untuk memeriksa sengketa. Akan tetapi jika para pihak dalam perjanjian arbitrase sudah menentukan pilihan hukum dari negara tertentu sebagai hukum yang akan dipergunakan dalam penyelesaian, maka hukum yang dipilih para pihak yang akan diberlakukan.
Sesuai dengan Pasal 27 UU Nomor 30 Tahun 1999, "Semua pemeriksaan sengketa oleh arbiter atau majelis arbiter dilakukan secara tertutup". Sifat tertutup tersebut adalah untuk menegaskan sifat kerahasiaan penyelesaian sengketa melalui arbitrase, yakni bahwa segala sesuatu yang terjadi pemeriksaan melalui arbitrase tidak boleh disiarkan kepada publik atau pers oleh masing-masing pihak.

Hal ini berbeda dengan ketentuan acara perdata yang berlaku di pengadilan negeri yang pada prinsipnya terbuka untuk umum. Artinya dalam pemeriksaan perkara perdata di pengadilan negeri setiap orang diperbolehkan hadir untuk mengikuti jalannya persidangan. Secara formal asas ini memberikan kesempatan bagi kontrol sosial dan memberikan perlindungan hak asasi manusia dalam bidang peradilan, dan asas ini bertujuan untuk menjamin proses peradilan yang fair dan obyektif tidak memihak serta terwujudnya putusan hakim yang adil (Muhammad Nasir, 2005:13).

Kemudian, dalam Pasal 28 UU Nomor 30 Tahun 1999 dinyatakan bahwa "bahasa yang digunakan dalam semua proses arbitrase adalah bahasa Indonesia, kecuali atas persetujuan arbiter atau majelis arbitrase para pihak dapat memilih bahasa lain yang akan digunakan".

Selanjutnya, dalam Pasal 29 UU Nomor 30 Tahun 1999 disebutkan:

(1) Para pihak yang bersengketa mempunyai hak dan kesempatan yang sama dalam mengemukakan pendapat masing-masing. 
(2) Para pihak yang bersengketa dapat diwakili oleh kuasanya dengan surat kuasa khusus.

Dengan demikian, ketentuan dalam Pasal 28 dan Pasal 29 UU Nomor 30 Tahun 1999 tersebut menghendaki bahwa bahasa yang digunakan dalam pemeriksaan arbitrase adalah bahasa Indonesia, penggunaan bahasa lain dimungkinkan akan tetapi dengan persetujuan arbiter atau majelis arbiter. Dan para pihak yang bersengketa mempunyai hak yang sama untuk mengeluarkan pendapat serta dapat diwakili oleh kuasanya.

Untuk menjamin kepastian penyelesaian pemeriksaan arbitrase Pasal 48 UU Nomor 30 Tahun 1999 menentukan bahwa pada dasarnya pemeriksaan atas sengketa dalam arbitrase harus dilakukan dalam waktu paling lama 180 hari sejak arbiter atau majelis arbiter terbentuk. Dengan persetujuan para pihak dan apabila diperlukan, jangka waktu tersebut dapat diperpanjang. Dalam Pasal 33 UU Nomor 30 Tahun 1999 ditegaskan bahwa arbiter atau majelis arbitrase berwenang untuk memperpanjang jangka waktu tugasnya jika:

a. Diajukan permohonan oleh salah satu pihak mengenai hal khusus tertentu, misalnya, karena adanya gugatan antara atau gugatan isidentil di luar pokok sengketa seperti permohonan jaminan sebagaimana dimaksud dalam hukum acara perdata.

b. Sebagai akibat ditetapkan putusan provisional atau putusan sela lainnya. c. Dianggap perlu oleh arbiter atau majelis arbitrase untuk kepentingan pemeriksaan.

Pihak ketiga yang berada di luar perjanjian arbitrase menurut Pasal 30 UU Nomor 30 Tahun 1999, dapat turut serta dan menggabungkan diri dalam proses penyelesaian sengketa melalui arbitrase. Keikutsertaan pihak ketiga ini dimungkinkan dengan syarat disepakati oleh para pihak yang bersengketa, serta disetujui oleh arbiter atau majelis arbitrase yang memeriksa sengketa.

Dalam pemeriksaan sengketa, arbiter atau majelis arbitrase atau atas permintaan para pihak dapat mendatangkan seorang saksi atau lebih atau seorang saksi ahli atau lebih untuk didengar keterangannya. Kemudian para pihak berhak memohon pendapat yang mengikat dari lembaga arbitrase atas hubungan hukum tertentu dari suatu perjanjian. Misalnya mengenai penafsiran ketentuan yang kurang jelas, penambahan atau perubahan pada ketentuan yang berhubungan dengan timbulnya keadaan baru. Terhadap pendapat tersebut tidak dapat dilakukan perlawanan melalui upaya hukum apapun.

Putusan dalam pemeriksaan sengketa melalui arbitrase dijatuhkan dalam waktu paling lama tiga puluh (30) hari setelah pemeriksaan ditutup. Dalam waktu empat belas (14) hari setelah putusan diterima, para pihak dapat mengajukan koreksi kepada arbiter atau majelis arbitrase terhadap kekeliruan administratif misal koreksi karena kesalahan pengetikan, penulisan nama, alamat dan lain-lain, tetapi tidak mengubah substansi putusan. 
Putusan yang diambil oleh Arbiter atau majelis arbitrase adalah berdasarkan ketentuan hukum, atau berdasarkan keadilan dan kepatutan. Dalam hal arbiter diberi kebebasan untuk memberikan putusan berdasarkan keadilan dan kepatutan, maka peraturan perundang-undangan dapat dikesampingkan kecuali aturan hukum yang bersifat memaksa. Sebaliknya jika arbiter tidak diberi kewenangan untuk memberikan putusan berdasarkan keadilan dan kepatutan, maka arbiter hanya dapat memberikan putusan berdasarkan kaidah hukum materil sebagaimana yang dilakukan oleh hakim.

Untuk biaya arbitrase menurut Pasal 76 UU Nomor 30 Tahun 1999, ditentukan oleh arbiter, dan biaya tersebut dibebankan kepada pihak yang kalah, kecuali dalam hal tuntutan hanya dikabulkan sebagian, biaya arbitrase dibebankan kepada para pihak secara seimbang. Biaya arbitrase tersebut meliputi honorarium arbiter, biaya perjalanan dan biaya lain yang dikeluarkan arbiter, biaya saksi dan atau saksi ahli yang diperlukan dalam pemeriksaan sengketa, dan biaya administrasi.

Kebebasan arbiter dalam menentukan biaya arbitrase tergantung dari perjanjian arbitrase. Arbiter tidak wajib memberikan alasan apabila ia menetapkan biaya dengan cara yang berbeda dari aturan yang biasa ditetapkan oleh suatu lembaga misalnya seperti BANI, yang menetapkan biaya arbitrase dalam suatu daftar terpisah dan terlampir pada peraturan prosedur arbitrase. Oleh karena itu harus ada perjanjian yang jelas antara para pihak yang bersengketa dengan arbiter untuk biaya arbitrase. Selanjutnya arbiter juga berhak atas biaya tambahan jika waktu arbitrase yang telah disepakati perlu diperpanjang.

Berdasarkan

mekanisme penyelesaian sengketa melalui arbitrase di atas dapat dikemukakan, bahwa proses arbitrase mempunyai kelebihan jika dibandingkan penyelesaian sengketa melalui pengadilan. Rachmadi Usman mengemukakan ada 5 (lima) kelebihan penyelesaian sengketa melalui arbitrase yakni:

a. Dijamin kerahasiaan sengketa para pihak.

b. Dapat dihindari kelambatan yang diakibatkan karena hal prosedural dan dan administratif.

c. Para pihak dapat memilih arbiter yang menurut kenyakinannya mempunyai pengetahuan, pengalaman, latar belakang yang cukup mengenai masalah yang disengketakan, serta jujur dan adil.

d. Para pihak dapat menentukan pilihan hukum untuk menyelesaikan masalahnya serta proses dan tempat penyelenggaraan arbitrase.

e. Putusan arbitrase merupakan putusan yang mengikat para pihak dengan melalui tata cara (prosedur) sederhana saja ataupun dapat dilaksanakan (Rachmadi Usman, Op. Cit:143).

Pendapat lain mengenai kelebihan penyelesaian sengketa melalui arbitrase dikemukakan oleh M. Husseyn Umar dan A. Supriyani Kardono, yakni:
a. Arbitrase memberikan prediktabilitas serta kepastian 
dalam proses penyelesaian sengketa.

b. Selama arbiternya seorang yang memang ahli dalam bidang bisnis yang sedang disengketakan, maka para pihak yang bersengketa memiliki kepercayaan terhadap arbiter dalam memahami permasalahan disengketakan. yang

c. Privasi merupakan factor penting dalam proses arbitrase dan masing-masing pihak memperoleh privasi tersebut sepanjang proses masih merupakan proses yang tertutup bagi umum dan putusan hanya ditujukan kepada para pihak yang bersengketa.

d. Peranan peradilan dalam proses arbitrase pada umumnya terbatas sehingga terjamin penyelesaiannya secara final.

e. Secara ekonomis proses arbitrase dianggap lebih cepat dan lebih murah dibandingkan proses berperkara di pengadilan (M. Husseyn Umar dan A. Supriyani dalam Rachmadi Usman, Ibid:142).

Berkaitan dengan kelebihan penyelesaian sengketa melalui arbitrase di atas, dapat dikemukakan bahwa arbitrase memberikan kebebasan para pihak untuk menentukan arbiter sesuai dengan kemampuan dan keahlian arbiter. Kemudian sifat penyelesaian sengketa yang tertutup sehingga menjamin kerahasiaan para pihak yang bersengketa dari publikasi yang merugikan. Selanjutnya para pihak dapat menentukan tempat arbitrase dan pilihan hukum dalam penyelesaian sengketa, serta proses penyelesaian sengketa lebih cepat dibandingkan dengan proses di pengadilan karena proses penyelesaian sengketa dapat diselesaikan dalam jangka waktu tidak lebih 180 hari.

B. Kekuatan Hukum Putusan Arbitrase Pada Sengketa Jasa Konstruksi

Putusan arbitrase pada dasarnya dapat dibedakan atas dua (2) macam, yaitu putusan arbitrase nasional dan putusan arbitrase internasional. Pengertian putusan arbitrase nasional tidak diatur dalam UU Nomor 30 Tahun 1999. Pasal 1 angka (9) UU Nomor 30 Tahun 1999 hanya merumuskan pengertian putusan arbitrase internasional, adalah "putusan yang dijatuhkan oleh suatu lembaga arbitrase atau arbiter perorangan di luar wilayah hukum Republik Indonesia, atau putusan suatu lembaga arbitrase atau arbiter perorangan yang menurut ketentuan hukum Republik Indonesia dianggap sebagai suatu putusan arbitrase internasional".

Oleh karena ketiadaan pengaturan mengenai pengertian putusan arbitrase nasional dalam UU Nomor 30 Tahun 1999, maka dengan menggunakan penafsiran argumentum a contrario dapat dirumuskan bahwa putusan arbitrase nasional adalah putusan yang dijatuhkan oleh suatu lembaga arbitrase atau arbitrase perorangan di wilayah hukum Republik Indonesia berdasarkan ketentuan hukum Republik Indonesia. Sepanjang putusan tersebut dibuat berdasarkan dan dilakukan di Indonesia, maka putusan arbitrase ini termasuk dalam putusan arbitrase nasional.

Mengenai isi putusan arbitrase nasional menurut Pasal 54 ayat (1) UU Nomor 30 Tahun 1999 harus memuat : 
a. kepala putusan yang berbunyi "Demi Keadilan berdasarkan Ketuhanan Yang Maha Esa"

b. nama lengkap dan alamat para pihak

c. uraian singkat sengketa

d. pendirian para pihak

e. nama lengkap dan alamat arbiter

f. pertimbangan dan kesimpulan arbiter atau majelis arbittrase mengenai kesluruhan sengketa

g. pendapat tiap-tiap arbiter dalam hal terdapat perbedaan pendapat dalam majelis arbitrase

h. amar putusan

i. tempat dan tanggal putusan dan

j. tanda tangan arbiter atau majelis arbitrase.

Putusan arbitrase yang memuat irahirah Demi Keadilan berdasarkan Ketuhanan Yang Maha Esa, menunjukkan bahwa putusan arbitrase mempunyai kekuatan hukum yang sama dengan putusan pengadilan. Hal ini sesuai dengan bunyi Pasal 4 UndangUndang Nomor 4 Tahun 2004 yang merupakan perubahan dari UndangUndang Nomor 35 Tahun 1999 dan Undang-Undang Nomor 14 Tahun 1970 tentang Kekuasaan Kehakiman yang menyatakan bahwa peradilan dilakukan Demi Keadilan Berdasarkan Ketuhanan Yang Maha Esa. Kalimat ini merupakan lex generalis yang berlaku secara umum dan turunan merupakan lex specialis yang merupakan syarat mutlak pada setiap putusan pengadilan (Susilawetty, Op.Cit:10).

Kemudian berdasarkan Pasal 60 UU Nomor 30 Tahun 1999, putusan arbitrase tersebut bersifat final dan mempunyai kekuatan hukum tetap dan mengikat para pihak, dengan demikian tidak dapat diajukan banding, kasasi, atau peninjauan kembali. Untuk dapat putusan arbitrase tersebut dilaksanakan, maka putusan arbitrase tersebut harus didaftarkan pada Pengadilan Negeri yang wilayah hukumnya meliputi tempat termohon dalam jangka waktu tiga puluh (30) hari terhitung sejak putusan diucapkan. Apabila para pihak tidak bersedia memenuhi pelaksanaan putusan tersebut secara sukarela, putusan tersebut dapat dilaksanakan berdasarkan perintah Ketua Pengadilan Negeri atas permohonan salah satu pihak yang bersengketa. Perintah eksekusi dari Ketua Pengadilan Negeri diberikan (Pasal 61) dalam jangka waktu paling lama tiga puluh (30) hari sejak permintaan eksekusi diterima.

Putusan arbitrase yang bersifat final dan mengikat tersebut karena beberapa hal dapat dibatalkan. Pembatalan putusan arbitrase ini hanya dapat dilakukan jika terdapat hal-hal yang luar biasa. Pasal 70 UU Nomor 30 Tahun 1999 menentukan bahwa putusan arbitrase dapat dibatalkan apabila diduga mengandung unsur-unsur sebagai berikut:

a. Surat atau dokumen yang diajukan dalam pemeriksaan, setelah putusan dijatuhkan, diakui palsu atau dinyatakan palsu.

b. Setelah putusan diambil, ditemukan dokumen yang bersifat menentukan, yang disembunyikan oleh pihak lawan, atau

c. Putusan diambil dari hasil tipu muslihat yang dilakukan oleh salah satu pihak dalam pemeriksaan sengketa. 
Dari alasan pembatalan yang tersebut di atas, upaya pembatalan tersebut merupakan upaya hukum luar biasa. Karena itu menurut Munir Fuady, "sungguhpun tidak dengan tegas disebutkan dalam undang-undang, jika kita melihat alasan-alasan pembatalan putusan arbitrase, upaya hukum pembatalan tersebut merupakan hukum memaksa yang tidak dapat dikesampingkan oleh kedua belah pihak" (Munir Fuady, Op. Cit:110).

Permohonan pembatalan putusan arbitrase tersebut berdasarkan Pasal 70, 71, dan 72 UU Nomor 30 Tahun 1999 beserta penjelasannya, diajukan kepada ketua pengadilan negeri. Pengajuannya dilakukan secara tertulis dalam jangka waktu 30 hari terhitung sejak penyerahan dan pendaftaran putusan arbitrase kepada panitera pengadilan negeri. Hal ini berarti permohonan pembatalan hanya dapat dilakukan terhadap putusan arbitrase yang sudah didaftarkan di pengadilan negeri.

Kewenangan untuk memeriksa tuntutan pembatalan putusan arbitrase berada pada ketua pengadilan negeri. Pemeriksaannya dilakukan menurut proses peradilan perdata. Putusan atas permohonan pembatalan putusan arbitrase harus sudah ditetapkan dalam jangka waktu 30 puluh hari sejak permohonan pembatalan putusan arbitrase diterima.

Apabila permohonan pembatalan putusan arbitrase dikabulkan, ketua pengadilan negeri menentukan lebih lanjut akibat dari pembatalan putusan tersebut. Ketua Pengadilan Negeri dapat memutuskan bahwa sengketa yang dibatalkan tersebut akan diperiksa kembali oleh Arbiter yang sama, Arbiter lainnya atau sengketa tersebut tidak dapat diselesaikan melalui arbitrase. Sebaliknya jika alasan permohonan pembatalan putusan tersebut tidak terbukti, maka ketua pengadilan negeri akan menolak permohonan pembatalan tersebut. Terhadap putusan pemohonan pembatalan tersebut, UU Nomor 30 Tahun 1999 masih memberikan kemungkinan upaya hukum banding (kasasi) ke Mahkamah Agung yang memutus dalam tingkat pertama dan terakhir.

Sebagaimana telah dikemukakan sebelumnya bahwa putusan arbitrase terdiri atas putusan arbitrase nasional dan putusan arbitrase internasional. Untuk pengakuan dan pelaksanaan arbitrase internasional pengaturannya terdapat dalam Pasal 65 dan Pasal 66 UU Nomor 30 Tahun 1999. Dalam Pasal 65 disebutkan bahwa "Yang berwenang menangani masalah pengakuan dan pelaksanaan Putusan Arbitrase Internasional adalah Pengadilan Negeri Jakarta Pusat". Kemudian pelaksanaan dan pengakuan putusan arbitrase internasional juga harus memenuhi persyaratan yang bersifat substantif sebagaimana yang dimuat dalam Pasal 66 UU Nomor 30 Tahun 1999 jo PERMA No. 1 Tahun 1990 tentang Tata Cara Pelaksanaan Arbitrase Asing, yakni:

a. Putusan Arbitrase Internasional dijatuhkan oleh arbiter atau majelis arbitrase di suatu Negara yang dengan Negara Indonesia terikat pada perjanjian, baik secara belateral maupun multilateral, mengenai pengakuan dan pelaksanaan Putusan Arbitrase Internasional; 
b. Putusan Arbitrase Internasional sebagaimana dimaksud dalam huruf a terbatas pada putusan yang menurut ketentuan hukum Indonesia termasuk dalam ruang lingkup hukum perdagangan;

c. Putusan Arbitrase Internasional sebagaimana dimaksud dalam huruf a hanya dapat dilaksanakan di Indonesia terbatas pada putusan yang tidak bertentangan dengan ketertiban umum;

d. Putusan Arbitrase Internasional dapat dilaksanakan di Indonesia setelah memperoleh eksekutor dari Ketua Pengadilan Negeri Jakarta Pusat; dan

e. Putusan Arbitrase Internasional sebagaimana dimaksud dalam huruf a yang menyangkut Negara Republik Indonesia sebagai salah satu pihak dalam sengketa, hanya dapat dilaksanakan setelah memperoleh eksekuatur dari Mahkamah Agung Republik Indonesia yang selanjutnya dilimpahkan kepada Pengadilan Negeri Jakarta Pusat.

Berdasarkan Pasal 66 huruf b dan c di atas yang mengatur obyek sengketa yang dapat dijatuhkan putusan, adalah terbatas pada ruang lingkup hukum perdagangan dan putusan tersebut hanya dapat dilaksanakan di Indonesia apabila putusan tersebut tidak bertentangan dengan ketertiban umum. Berkaitan dengan hal tersebut, M. Yahya Harahap mengemukakan bahwa putusan arbitrase asing atau internasional adalah "putusan yang dijatuhkan (diambil) di luar wilayah hukum Republik Indonesia"( M. Yahya Harahap, Op. Cit:438). Lebih lanjut menurut M. Yahya Harahap, ciri dari putusan arbitrase asing tersebut antara lain:

a. Didasarkan pada faktor wilayah atau teritorial

Yakni setiap putusan arbitrase yang dijatuhkan di luar territorial Republik Indonesia, dikualifikasi sebagai putusan arbitrase asing. Meskipun pihak-pihak yang terlibat dalam putusan terdiri dari orang-orang Indonesia dan samasama warga Negara Indonesia, namun jika putusan dijatuhkan di luar wilayah hukum Republik Indonesia, dengan sendirinya menurut hukum putusan tersebut dikualifikasi sebagai putusan arbitrase asing. Jadi pihak-pihak yang terkait di dalamnya dapat terdiri sesame perseorangan, antara perseorangan dengan badan hukum, atau antara badan hukum dengan sesame badan hukum (Ibid:437-441).

b. Putusan didasarkan atas konvensi Internasional

Apabila jika para pihak sudah sepakat mengenai hukum yang akan dipergunakan dalam menyelesaikan sengketa bersumber pada konvensi internasional, misalnya sengketa diselesaikan menurut ICSID atau UNCITRAL Arbitration Rule, kemudian pengakuan eksekusinya diminta pada Negara di tempat mana diputuskan, maka putusan tersebut tergolong putusan arbitrase asing.

Dalam hal ini bukan hanya factor territorial yang harus mengalah tetapi juga factor kesamaan 
kewarganegaraan dan system tata hukum harus tunduk kepadanya. Meskipun pihak-pihak yang terlibat dalam putusan tersebut adalah sesame warga Negara Indonesia, putusan dijatuhkan dalam wilayah hukum Indonesia, namun karena hukum yang mereka sepakati adalah konvensi internasional maka putusan yang dijatuhkan tergolong putusan asing.

Selanjutnya pelaksanaan putusan arbitrase internasional untuk dapat diakui dan dilaksanakan di Indonesia harus didaftarkan di Pengadilan Negeri Jakarta Pusat, dengan disertai persyaratan administrasi sebagaimana yang termuat dalam Pasal 67 UU Nomor 30 Tahun 1999, sebagai berikut:

a. Lembar asli atau salinan otentik Putusan Arbitrase Internasional, sesuai ketentuan perihal otentifikasi dokumen asing, dan naskah terjemahan resminya dalam Bahasa Indonesia;

b. Lembar asli atau salinan otentik perjanjian yang menjadi dasar Putusan Arbitrase Internasional sesuai ketentuan perihal otentifikasi dokumen asing, dan naskah terjemahan resminya dalam Bahasa Indonesia;

c. Keterangan dari Perwakilan Diplomatik Republik Indonesia di Negara tempat Putusan Arbitrase Internasional tersebut ditetapkan, yang menyatakan bahwa Negara pemohon terikat pada perjanjian, baik secara belateral maupun multilateral dengan Negara Republik Indonesia perihal pengakuan dan Pelaksanaan

Putusan Arbitrase Internasional.

Terhadap putusan Ketua Pengadilan Negeri Jakarta Pusat yang mengakui dan melaksanakan arbitrase internasional bersifat final dan mengikat, sehingga tidak dapat diajukan banding atau kasasi. Akan tetapi terhadap putusan Ketua Pengadilan yang menolak untuk mengakui dan melaksanakan putusan arbitrase internasional, dapat diajukan kasasi ke Mahkamah Agung. Mahkamah Agung akan mempertimbangkan serta memutuskan setiap pengajuan kasasi dalam jangka waktu paling lama 90 hari setelah permohonan kasasi tersebut diterima oleh Mahkamah Agung. Terhadap putusan MA tersebut tidak dapat diajukan perlawanan.

Menurut PERMA Nomor 1 Tahun 1990 sebagaimana dikutip oleh $\mathrm{M}$. Yahya Harahap bahwa:

a. Putusan arbitrase internasional bersifat final dan binding sehingga setiap putusan arbitrase yang diajukan permintaan pengakuan dan eksekusinya di Indonesia dianggap sebagai putusan arbitrase asing yang berkekuatan hukum tetap. Dengan demikian, pengadilan Indonesia secara resmi telah mengakui dengan tegas sifat final dan binding yang melekat pada putusan arbitrase asing tersebut. Dengan adanya penegasan pengakuan bahwa putusan arbitrase asing yang diajukan permitaan eksekutornya kepada pengadilan sama halnya dengan putusan yang berkekuatan hukum tetap, jadi tidak ada alasan lagi untuk menolak atau 


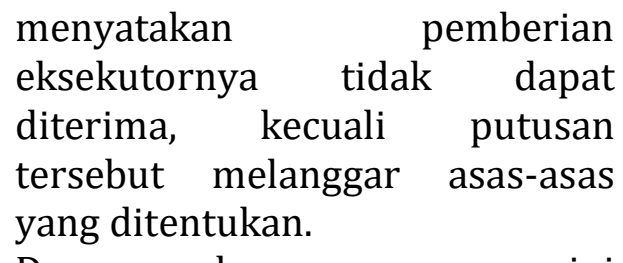

Dengan adanya penegasan ini maka pengadilan tidak berwenang untuk mempermasalahkan materi putusan. Tugas pokok pengadilan dalam melaksanakan fungsi eksekutor hanya meneliti apakah putusan arbitrase asing tersebut melanggar asas-asas yang dilarang atau aturan formal yang bersifat serius dan fundamental. Bila hal ini dilanggar maka pengadilan menolak pelaksanaan eksekusi, namum apabila tidak melanggar maka pengadilan harus melaksanakan eksekusi.

b. Asas Resiprositas

Asas ini berkaitan dengan apakah Negara di tempat mana putusan dijatuhkan mempunyai ikatan hubungan bilateral atau multilateral, maupun sama-sama terikat dalam suatu konvensi internasional dengan Indonesia, perihal pengakuan serta pelaksanaan putusan arbitrase asing. Hal ini sesuai dengan ketentuan Pasal 3 Perma Nomor 1 Tahun 1990 yang mengatur bahwa putusan arbitrase asing yang diakui serta dapat dilaksanakan di wilayah hukum Republik Indonesia, hanyalah putusan yang memenuhi syarat asas resiprositas. Jadi pengadilan di Indonesia mesti menolak eksekutor putusan arbitrase asing yang tidak mempunyai ikatan hubungan bilateral maupun multilateral dengan Negara Republik Indonesia dalam bidang arbitrase.

c. Pengakuan terbatas sepanjang Hukum Dagang

Pembatasan pengakuan Indonesia terhadap putusan arbitrase asing hanya meliputi sepanjang berkaitan dengan hukum dagang. Untuk menentukan apakan sesuatu kasus termasuk dalam lingkup hukum dagang atau tidak akan berpatokan kepada ketentuan system tata nilai hukum Indonesia, bukan berpatokan pada system tata nilai hukum Negara tempat dimana putusan dijatuhkan.

d. Asas Ketertiban Umum

Pengakuan atau eksekusi putusan arbitrase asing tidak boleh bertentangan dengan ketertiban umum dari Negara di tempat mana diminta eksekusinya. Jadi apabila putusan arbitrase asing bertentangan dengan ketertiban umum di Indonesia maka permintaan eksekutornya harus ditolak (Ibid:448-454).

Apabila diperhatikan uraian mengenai ketentuan kekuatan hukum putusan arbitrase nasional dan internasional di atas, pada prinsipnya kekuatan hukum putusan arbitrase tersebut bersifat final dan mengikat tetapi untuk pelaksanaan dan pengakuannya tetap membutuhkan Pengadilan Negeri untuk melaksanakan proses eksekusinya. 
Sehubungan dengan hal tersebut, jika dikaji dari Pasal 1338 ayat (1) KUHPerdata yang menyebutkan, "semua perjanjian yang dibuat secara sah berlaku sebagai undang-undang bagi mereka yang membuatnya", maka para pihak yang telah sepakat mengadakan perjanjian arbitrase dan menyerahkan proses penyelesaian sengketanya melalui arbitrase, sudah mengikat para pihak untuk mentaati dan melaksanakan putusan arbitrase tersebut sebagai perwujudan dari asas kebebasan berkontrak baik dalam arit materil maupun dalam arti formil.

Kemudian Pasal 1338 ayat (2) KUHPerdata menegaskan, "perjanjian tidak dapat ditarik kembali kecuali atas kesepakatan para pihak atau karena alasan-alasan yang ditentukan undangundang". Ketentuan ayat (2) menunjukan bahwa perjanjian arbitrase yang kemudian menghasilkan putusan arbitrase tidak dapat dibatalkan kecuali atas alasan-alasan yang ditentukan dalam undang-undang. Hal ini berarti setiap pembatalan perjanjian arbitrase ataupun putusan arbitrase hanya dapat dilakukan sesuai peraturan perundangundangan.

Selanjutnya Pasal 1338 ayat (3) KUHPerdata menyebutkan bahwa "perjanjian itu harus dilaksanakan dengan itikad baik". Itikad baik ini merupakan asas bahwa para pihak dalam perjanjian harus melaksanakan substansi dari perjanjian. Menurut Madjedi Hasan, "itikad baik tidak terbatas pada waktu mengadakan hubungan hukum tetapi juga pada waktu melaksanakan hak dan kewajiban yang timbul dari hubungan hukum tersebut. Pengertian itikad baik itu juga mengandung asas kepantasan dan kepatutan (redelijkheid en bilijkheid) (Madjedi Hasan, 2005:26).

Berdasarkan Pasal 1338 KUHPerdata tersebut, ketentuan mengenai kekuatan putusan arbitrase yang tertuang dalam UU Nomor 30 Tahun 1999 harus didaftarkan ke Pengadilan Negeri untuk proses eksekusinya, seharusnya bukan merupakan suatu ketentuan yang bersifat memaksa tetapi merupakan ketentuan yang bersifat kebolehan. Artinya putusan arbitrase tersebut boleh didaftarkan dan boleh juga tidak didaftarkan.

\section{Kesimpulan}

Berdasarkan pembahasan pada bab sebelumnya dapat disimpulkan hal-hal sebagai berikut:

1. Penyelesaian sengketa melalui arbitrase, merupakan salah satu cara penyelesaian sengketa di luar pengadilan. Mekanisme penyelesaian sengketanya dimulai dari tahap pemberitahuan dan jawaban kepada para pihak, kemudian diikuti dengan pemilihan dan pengangkatan arbiter, dan diakhiri dengan pemeriksaan dan putusan. Kesemua tahapan itu menunjukan bahwa penyelesaian sengketa melalui arbitrase memiliki kelebihan dibandingkan dengan penyelesaian melalui pengadilan. Kelebihannya adalah adanya kebebasan para pihak untuk menentukan arbiter, terjaminnya kerahasiaan para pihak karena penyelesaian sengketa dilakukan secara tertutup. Selanjutnya para pihak dapat menentukan tempat arbitrase dan pilihan hukum dalam penyelesaian sengketa, serta proses 
penyelesaian sengketa lebih cepat yakni dapat diselesaikan tidak lebih dari 180 hari.

2. Kekuatan hukum dari putusan arbitrase adalah bersifat final dan mengikat, tetapi pengakuan dan pelaksanaan putusannya tetap harus didaftarkan ke Pengadilan Negeri. Ketentuan putusan arbitrase tersebut harus didaftarkan di Pengadilan agar dapat dilaksanakan, merupakan ketentuan yang bersifat memaksa dan tidak dapat dikesampingkan. Hal ini dimaksudkan untuk menjamin kepastian hukum bagi para pihak, jika dikemudian hari ada salah satu pihak yang akan melanggar kesepakatan tidak melaksanakan putusana arbitrase tersebut.

\section{Saran}

1. Penyelesaian sengketa melalui arbitrase berbeda dengan penyelesaian sengketa melalui pengadilan, karena prosesnya dapat dilakukan menurut kebiasaan dan kesepakatan para pihak atau berdasarkan peraturan perundang-undangan. Untuk menjamin efektivitas penyelesaian sengketa melalui arbitrase, maka para pihak yang bersengketa seyogyanya mengikuti mekanisme penyelesaian sengketa yang telah ditetapkan oleh peraturan perundang-undangan yang berlaku atau peraturan dari lembaga arbitrase tertentu yang dipilih para pihak.

2. Putusan arbitrase mempunyai kekuatan hukum yang tetap dan mengikat sehingga putusan tersebut dapat dilaksanakan.
Tetapi kekuatan mengikat tersebut masih digantungkan pelaksanaannya oleh pengadilan. Pengadilan mempunyai kewajiban mengeksekusi putusan arbitrase sesuai perintah undang-undang, namun undang-undang tidak memuat sanksi jika pengadilan tidak melaksanakan eksekusi. Oleh karena itu ketentuan mengenai pengakuan dan pelaksanaan dari putusan arbitrase seyogyanya hanya merupakan kententuan yang bersifat kebolehan bukan keharusan.

\section{Daftar Pustaka}

Abdurrasyid, Priyatna. 2002, Arbitrase \& Alternatif Penyelesaian Sengketa Suatu Pengantar, Fikahati Aneska, Jakarta.

Adolf, Huala. 1994, Hukum Arbitrase Komersial Internasional, Raja Grafindo Persada, Jakarta.

Faisal Salam, Moch. 2007, Penyelesaian Sengketa Bisnis Secara Nasional dan Internasional, Mandar Maju, Bandung.

Hasan, Madjedi. 2005, Pacta Sunt

Servanda: Penerapan Asas Janji itu Mengikat, PT. Fikahati Aneska, Jakarta.

Hendra, Frans. 2011, Hukum Penyelesaian Sengketa Arbitrase Nasional Indonesia dan Internasional, Edisi Kedua, Sinar Grafika, Jakarta.

Margono, Suyud. 2004, ADR \& Arbitrase Proses Pelembagaan dan Aspek Hukum, Ghalia Indonesia, Jakarta.

Nasir, Muhammad. 2005, Hukum Acara Perdata, Djambatan, Jakarta. 
Subekti, R. 1992, Arbitrase Perdagangan, Bina Cipta, Bandung.

Soemartono, Gatot. 2006, Arbitrase dan Mediasi di Indonesia, Gramedia Pustaka Utama, Jakarta.

Susilawetty, 2013, Arbitrase Dan Alternatif Penyelesaian Sengketa Ditinjau Dalam Perspektif Peraturan Perundang-undangan, Gramata Publishing, Jakarta.

Sutantio, Retnowulan dan Oeripkartawinata, Iskandar. 1988, Hukum Acara Perdata dalam Teori dan Praktek, Alumni, Bandung.

Sutiyoso, Bambang. 2006, Penyelesaian Sengketa Bisnis: Solusi dan Antisipasi bagi Peminat Bisnis dalam Menghadapi Sengketa Kini dan Mendatang, Citra Media, Yogyakarta.

Usman, Rachmadi. 2013, Pilihan Penyelesaian Sengketa di Luar Pengadilan, Citra Aditya Bakti, Bandung.

Yahya, M. Harahap. 1991, Arbitrase, Pustaka Kartini, Jakarta.

--------- 1997, Beberapa Tinjauan Sistem Peradilan Dan Penyelesaian Sengketa, Citra Aditya Bakti, Bandung. 